\title{
HUBUNGAN ANTARA POWER OTOT LENGAN DAN OTOT TUNGKAI DENGAN HASIL SPIKE SEMI PADA CABANG OLAHRAGA BOLA VOLI
}

\author{
Helda Heldayana, Aming Supriyatna, Iman Imanudin \\ Fakultas Pendidikan Olahraga dan Kesehatan \\ Universitas Pendidikan Indonesia, Jl. Dr. Setiabudhi No. 299 Bandung \\ Em@il: Helda_heldayana@yahoo.com
}

\begin{abstract}
Abstrak
Penelitian ini dilatar belakangi oleh pentingnya komponen-komponen kondisi fisik terhadap hasil pukulan spike semi dalam permainan bola voli diantaranya power otot lengan dan otot tungkai. Tujuan dari penelitian ini untuk mengetahui hubungan antara power otot lengan dan otot tungkai dengan hasil spike semi dalam permainan bola voli. Penelitian ini menggunakan metode deskriptif dengan teknik korelasional. Sampel yang digunakan dalam dalam penelitian ini adalah anggota club bola voli PASUNDAN Bandung sebanyak 12 orang yang diambil dengan menggunakan teknik purposive sampling. Instrumen yang digunakan dalam penelitian ini adalah tes soft ball throw untuk tes power otot lengan, tes digital vertical jump untuk tes otot tungkai dan tes spike semi bola voli. Menunjukkan terdapat hubungan antara power otot lengan dan otot tungkai dengan hasil spike semi. Dengan hasil penelitian power otot lengan dengan hasil spike semi adalah $\mathrm{r}=$ 0.697 , nilai sig. $0.012<0.05$, sedangkan otot tungkai dengan hasil spike semi adalah $\mathrm{r}=$ 0.652 , nilai sig. $0.022<0.05$, dan secara bersama-sama antara power otot lengan dan otot tungkai dengan hasil spike semi adalah $\mathrm{r}=0.780$, nilai sig. $0.015<0.05$.

Kata kunci: bola voli, power otot lengan, otot tungkai, dan hasil spike semi.
\end{abstract}

\section{PENDAHULUAN}

Olahraga adalah olah gerak badan yang melibatkan otot besar dan dilakukan secara teratur dan terencana dengan tujuan untuk menguatkan dan menyehatkan organ-organ tubuh. Salah satunya adalah olahraga permainan bola voli.

Bola voli adalah suatu bentuk olahraga permainan yang dimainkan oleh dua regu, dimana setiap regu berusaha memantulkan / memvoli bola dengan tangan atau lengan sebanyak tiga kali sentuhan secara bergantian dan berusaha melewatkan bola ke atas net, ke daerah lawan serta berusaha mematikannya untuk mendapatkan poin/skor. Seperti yang di jelaskan oleh Muhajir (2003:16) menjelaskan bahwa: "Bola voli adalah suatu cabang olahraga berbentuk memvoli bola di udara bolak-balik di atas jarring/net, dengan maksud dapat menjatuhkan bola di dalam petak lapangan lawan untuk mencari kemenangan".

Dalam permainan bola voli terdapat beberapa teknik merupakan dasar yang harus dikuasai oleh seorang pemain bola voli agar dapat bermain bola voli dengan baik. Menurut Dieter Beutelstahl (1986:9) bahwa teknikteknik dasar permainan bola voli tersebut meliputi: "(1) servis, (2) pass bawah, (3) pass atas, (4) smash/spike, (5) blok, dan (6) pertahanan". Sedangkan untuk dapat berprestasi selain diperlukan penguasaan teknik, taktik, fisik yang prima, juga diperlukan kemampuan mental yang bagus. Dalam permainan bola voli ada dua masalah penting 
yang harus dikuasai oleh seorang atlet. Kosasih (1985:109) menjelaskan bahwa: "Yang perlu dikuasai oleh seorang atlet dalam permainan bola voli adalah: (1) Teknik penguasaan bola, dan (2) Teknik permainan."

Kedua teknik tersebut mempunyai hubungan yang sangat erat dalam menciptakan suasana permainan yang baik dan akan memberikan hasil atau prestasi yang baik pula.

Untuk mencapai suatu prestasi yang maksimal yang di inginkan ada beberapa persyaratan yang harus dikuasai oleh atlet. Suharno (1982:2) menjelaskan bahwa: "Untuk mencapai prestasi yang maksimal atlet harus mempunyai beberapa persyaratan yaitu: (1) Kesehatan tubuh, (2) Bentuk tubuh, (3) Kondisi fisik, (4) Penguasaan teknik, (5) Penguasaan taktik, dan (6) Memiliki kejiwaan dan kepribadian yang baik".

Hal ini juga senada dengan pendapat Harsono (1988:100) yang menjelaskan bahwa: "Ada beberapa aspek yang perlu dikuasai dan dilatih secara seksama oleh atlet yaitu: (1) Latihan fisik (physical training), (2) Latihan teknik (technical training), (3) Latihan taktik (tactical training), (4) Latihan mental (psychological training)."

Dari penjelasan di atas dapat disimpulkan bahwa banyak sekali persyaratan yang harus dimiliki oleh seorang atlet untuk dapat bermain bola voli dengan baik apalagi untuk dapat berprestasi. Dengan memiliki persyaratanpersyaratan tersebut atlet dapat bertanding dengan baik. Salah satu dari persyaratan tersebut yang paling mendasar adalah penguasaan teknik dan kemampuan fisik.

Diantara teknik permainan bola voli, nampaknya teknik serangan dari atas net (jaring) cukup sulit untuk dikuasai oleh pemain, terutama jika teknik serangan itu dilakukan dengan spike. Kesulitan utama untuk melakukan spike bola voli adalah tingginya jaring yang melebihi jangkauan lengan para pemain yang relative memiliki postur tubuh yang jauh lebih pendek dari tinggi jaring tersebut, sehingga bola yang seharusnya dipukul dari atas jaring tidak dapat dipukul secara maksimal. Namun demikian hal tersebut bukan suatu masalah besar jika kondisi fisiknya baik.

Komponen-komponen kondisi fisik yang mendukung pencapaian gerak dalam olahraga adalah kekuatan (strength), daya tahan (endurance), daya ledak (muscular power), kecepatan (speed), kelentukan (flexibility), keseimbangan (balance), koordinasi (coordination), kelincahan (agility), ketepatan (accuracy), reaksi (reaction). Sedangkan komponen-komponen kondisi fisik yang mendukung keterampilan spike adalah power otot lengan dan otot tungkai.

Dengan demikian dapatlah dikatakan bahwa kondisi fisik seperti power otot lengan, dan otot tungkai merupakan kondisi fisik yang memegang peranan penting dalam olahraga bola voli khususnya dalam melakukan spike, karena dapat memperoleh pukulan spike yang keras dan tajam.

Oleh sebab itu spike pada permainan bola voli adalah salah satu teknik bermain yang sangat menentukan dalam permainan bola voli. Spike dalam permainan bola voli dipergunakan ketika mengadakan penyerangan. Pukulan yang dilakukan pada penyerangan dengan teknik ini melibatkan berbagai kemampuan tubuh karena sasarannya adalah kecepatan dan ketepatan bola hasil spike untuk memperoleh kemenangan.

Berdasarkan paparan di atas penulis tertarik untuk melakukan penelitian terhadap atlet-atlet bola voli yang tergabung dalam club bola voli PASUNDAN yang berada di Kota Bandung mengenai kebenaran apakah hubungan antara power otot lengan dengan otot tungkai dapat mempengaruhi terhadap hasil spike semi. Alasan penulis memilih club tersebut karena mayoritas atletnya laki-laki semua dan club tersebut sudah terkenal dan main di tingkat Nasional, atlet tersebut memiliki power otot lengan dan otot tungkai yang kuat sehingga dapat menghasilkan teknik spike yang baik.

Penelitian ini bertujuan untuk: (1) Mengetahui hubungan fungsional antara power otot lengan dengan hasil spike semi pada 
cabang olahraga bola voli club PASUNDAN; (2) Mengetahui hubungan fungsional antara otot tungkai dengan hasil spike semi pada cabang olahraga bola voli club PASUNDAN. (3) Mengetahui hubungan fungsional antara power otot lengan dan otot tungkai dengan hasil spike semi pada cabang olahraga bola voli club PASUNDAN.

\section{METODE}

Tempat dilakukannya penelitian ini berlokasi di UPI Bandung yang berada di Jalan Dr. Setiabudhi No. 229 Bandung 40154. Populasi dalam penelitian ini adalah atlet bola voli yang tergabung dalam club bola voli PASUNDAN Bandung sebanyak 20 orang.

Pengambilan sampel dalam penelitian ini menggunakan teknik purposive sampling yaitu teknik pengambilan sampel dengan pertimbangan tertentu. sampel yang diperoleh sebanyak 12 orang. Adapun karakteristik dari sampel tersebut adalah sebagai berikut: (1) Merupakan atlet atau anggota yang terdaftar di club bola voli PASUNDAN; (2) Atlet yang dijadikan sampel berumur 20-23 tahun; (3) Keaktifan dalam kehadiran dan proses latihan.; (4) Frekuensi latihan minimal 4 kali dalam seminggu; (5) Telah menguasai teknik pukulan spike semi. (6) Mempunyai pengalaman yang cukup baik dalam permainan dan pertandingan bola voli; (7) Mempunyai pengalaman bertanding minimal tingkat daerah atau PORDA (Pekan Olahraga daerah).

Instrumen penelitian yang penulis gunakan mengacu pada buku tes pengukuran pendidikan olahraga oleh Nurhasan dan Abdul Narlan (2001:130), sebagai berikut: (1) Untuk mengukur power otot lengan digunakan tes soft ball throw, dengan validitas 0,73 dan reliabilitas 0,80. (Nurhasan, 1999:67); (2) Untuk mengukur otot tungkai digunakan tes Digital Vertical Jump, dengan validitas 0,989 dan reliabilitas 0,977 (Nurhasan dan Hasanudin, 2007, hlm.175). (3) Untuk mengetahui hasil keterampilan spike semi pada bola voli dilakukan tes spike (Nurhasan dan Hasanudin, 2007, hlm.225).

Pemecahan dari penelitian ini menggunakan metode penelitian kuantitatif, dengan pendekatan deskriptif korelatif. Menurut Sugiyono (2013, hlm. 14); Metode penelitian kuantitatif dapat diartikan sebagai metode penelitian yang berlandasakan pada filsafat positivisme, digunakan untuk meneliti pada populasi atau sampel tertentu, teknik pengambilan sampel pada umumnya dilakukan secara random, pengumpulan data menggunakan instrumen penelitian, analisis data bersifat kuantitatif atau statistik dengan tujuan untuk menguji hipotesis yang telah ditetapkan.

\section{HASIL DAN PEMBAHASAN}

Berdasarkan hasil pengolahan dan analisis data yang telah dilakukan, maka diperoleh temuan sebagai berikut:. Pertama, power otot lengan dengan hasil spike semi dalam permainan bola voli menunjukan hubungan yang positif dan signifikan. Hal tersebut menunjukan bahwa power otot lengan berperan dominan melakukan spike yaitu berperan pada kekuatan dan kecepatan pada saat melakukan spike, serta kemampuan memukul bola sekeras mungkin. Hal ini diharapkan, setiap pemain bola voli hendaknya selalu berupaya untuk meningkatkan power otot lengannya. Power otot lengan yang besar, memungkinkan hasil pukulan spike atau servisnya akan lebih keras dan cepat, sehingga tingkat keberhasilannya pun lebih besar pula. Troter mengatakan (1965:100): "Power, or sheerforce, is aquality of the service which can be developed to the extend that it makes a return of the service by the receiving team either completlely impossible or else definitely weakens the return by forcing the use of two, or three contack to bring the ball under control and tomake a return to the serving teams court". Oleh karena itu, maka seorang pemain yang akan melakukan spike harus memiliki power otot lengan yang bagus. Adapun dukungan power 
otot lengan terhadap hasil spike semi sebesar $48.6 \%$, dan $51.4 \%$ didukung oleh faktor-faktor lainnya.

Kedua, terdapat hubungan yang positif dan signifikan antara otot tungkai dengan hasil spike semi pada cabang olahraga bola voli. Hal ini menunjukan bahwa otot tungkai mempunyai peran penting terhadap hasil spike. Otot tungkai yang besar akan menghasilkan lompatan yang maksimal. Seorang pemain bola voli sangat diharuskan memiliki lompatan yang setinggi mungkin untuk melakukan spike. Seperti yang dikatakan oleh Theng (1973:38), bahwa "Pemain-pemain yang menghendaki dapat bermain sebagai penyerang harus mempunyai tenaga yang besar pada kakinya". Dijelaskan pula oleh Kosasih (1983:118), bahwa "Dalam melakukan spike sebaiknya kita dapat melompat setinggi mungkin, karena itu latihlah melompat sebanyak mungkin". Dengan demikian, dengan otot tungkai yang besar maka seorang spiker akan semakin tinggi menjangkau bola yang diumpankan tinggi diatas net pada saat memukul bola. Adapun dukungan otot tungkai terhadap hasil spike semi sebesar $42.5 \%$, dan $57.5 \%$ didukung oleh faktor-faktor lainnya.

Ketiga, power otot lengan dan otot tungkai secara bersama-sama dengan hasil spike semi dalam cabang olahraga bola voli menunjukan hubungan yang positif dan signifikan. Hal tersebut merupakan salah satu unsur komponen kondisi fisik yang sangat penting, terutama pada saat melakukan loncatan dan pukulan, karena dengan memilki kekuatan yang besar akan berdampak pada hasil yaitu loncatan yang tinggi dan pukulan yang keras dan tajam. Dengan pemahaman beberapa alasan tersebut, maka dapat diasumsikan bahwa salah satu keberhasilan dalam melakukan pukulan spike dalam permainan bola voli perlu di tunjang dengan kesiapan fisik di antaranya adalah kekuatan power otot lengan dan kekuatan otot tungkai diikuti dengan fleksibilitas sendi punggung.

Kontribusi power otot lengan dan otot tungkai sangat penting terhadap hasil spike semi dalam cabang olahraga bola voli. Pada penelitian ini power otot lengan memiliki koefisien korelasi yang sama dengan otot tungkai dan lebih signifikan dengan hasil spike semi. Hal ini dapat diartikan bahwa komponen kondisi fisik power otot lengan dan otot tungkai memberikan kontribusi yang lebih signifikan terhadap hasil spike semi dalam cabang olahraga bola voli. Adapun dukungan dari power otot lengan dan otot tungkai terhadap hasil spike semi sebesar $60.9 \%$, dan $39.1 \%$ didukung oleh faktor-faktor lainnya.

Pada saat di lapangan tidak hanya power otot lengan dan otot tungkai yang berpengaruh, lebih dari itu yang di butuhkan lainnya diantaranya otot puggung, otot bahu, fleksibilitas, koordinasi, kecepatan reaksi. Hal ini selaras dengan Pasurnay (1994:7) "Otot lengan, otot perut, otot punggung, dan otot bahu serta komponen kondisi fisik lainnya yang menunjang terhadap hasil lemparan atau pukulan". Maka dapat disimpulkan bahwa power otot lengan dan otot tungkai beserta komponen kondisi fisik lainnya dapat memberikan kontibusi terhadap hasil spike semi dalam cabang olahraga bola voli.

\section{KESIMPULAN}

Berdasarkan analisis data yang diperoleh dan uraian yang telah dikemukakan, maka kesimpulan yang dapat diambil dari hasil penelitian sebagai berikut: (1) Terdapat Hubungan Antara Power Otot Lengan dengan hasil spike semi pada cabang olahraga bola voli; (2) Terdapat Hubungan Antara Otot Tungkai dengan hasil spike semi pada cabang olahraga bola voli; (3) Terdapat Hubungan secara bersama-sama antara Power Otot Lengan dan Otot Tungkai dengan hasil spike semi pada cabang olahraga bola voli. 


\section{DAFTAR PUSTAKA}

Arikunto, Suharsimi. 1998. Prosedur Penelitian Suatu Pendekatan Praktek. Jakarta: Rineka Cipta.

Beachle, Thomas R dan Groves,Barney R. 2003. Latihan Beban (Terjemahan Razi Siregar). Jakarta: PT. Raja Grafindo Persada.

Bompa (1983). Komponen-komponen biomotorik. Jakarta.

Dieter, B. (2012) Belajar Bermain Bola Volley. Bandung: CV. Pionir Jaya.

Dieter, B. (1986:9) Belajar Bermain Bola Volley. Bandung: CV. Pionir Jaya.

Damiri (1994). Anatomi Manusia. Jakarta.

Damiri (1992:56). Anatomi Manusia. Jakarata.

Harsosno.(1988) Coaching dan Aspek-Aspek Psikologis Dalam Coaching.Jakarta: CV. Tambak Kusuma.

Http://id.wikipedia.org/wiki/Bola_voli.

Harsono.(1988). Latihan Fisik. Jakarta: Pusat Ilmu Olahraga Koni Pusat.

Harsono.(2001). Latihan Kondisi Fisik. Bandung.

Hidayat (1999:26). Latihan Beban. Bandung.

Ibrahim dan Sudjana (2004). Penelitian dan penilaian pendidikan. Bandung: Sinar Baru Algensindo.

Imam Hidayat. (1997). Biomekanika Olahraga. Bandung: FPOK-IKIP Bandung.

Lutan, R., et al (2007: 80). Metode Penelitian. Bandung: Departemen Pendidikan Nasional.

Muhajir, (2003:16) Pandua Bola Voli. Bandung: Departemen Pendidikan.

Maryanto, (1996) Teknik Dasar Permainan Bola Voli. Bandung: PT Media Indonesia.

Maryanto, (2006:23) Teknik Dasar Permainan Bola Voli. Bandung: PT Media Indonesia.

Nurhasan dan Abdul Narlan.(2001). Tes dan Pengukuran Pendidikan Olahraga. Tasikmalaya: PJKR FKIP UNSIL.

Nurhasan, H dan Cholil, D. (2007). Tes dan pengukuran keolahragaan. Bandung: Universitas Pendidikan Indonesia.

Purwanto.(2010) Statistika Untuk Penelitian.Surakarta: Pustaka Pelajar.

PBVSI, (1995). Metodologi Pelatihan. Jakarta: Sekum. PP. PBVSI.

Pasurnay (1994:7). Kondisi Fisik. Bandung.

Sajoto (1990:17). Latihan Kondisi Fisik. Jakarta: Hadiyaksa

Sugiyono. (2013) Metode Penelitian Kuantitatif, Kualitatif dan R\&D. Bandung: Alfabeta.

Singgih, S. (2012) Pandual Lengkap SPSS Versi 20. Jakarta: PT. Gramedia.

Suharno, HP. (1982:2). Metodologi Pelatihan. Yogyakarta: FPOK IKIP Yogyakarta.

Santoso, S. (2012). Panduan Lengkap SPSS Versi 20. Jakarta: PT Elex Media Komputindo.

Sugiyono. (2013). Statistika untuk Penelitian. Bandung: Alfabeta.

Yunus, M (1992:113) Teknik Spike Dalam Permainan Bola Voli. Bandung: Cendaki Pratama 